Sains Malaysiana 50(3)(2021): 655-665

http://dx.doi.org/10.17576/jsm-2021-5003-08

\title{
Caddisflies (Trichoptera, Insecta) as Bioindicator of Water Quality Assessment in a Small Stream in Northern Thailand
}

(Lalat Kadis (Trichoptera, Insecta) sebagai Biopenunjuk Penilai Kualiti air di Sungai Kecil di Utara Thailand)

\author{
Thamsenanupap, P., SeEtapan, K. \& Prommi, T.*
}

\begin{abstract}
The influence of environmental variables and the potential as bioindicators of larval stages of the species of Trichoptera were evaluated in a small stream in northern Thailand from January to November 2017. A total of 1,191 individual caddisfly larvae belonging to 7 families and 13 genus were found. The larvae of the family Glossosomatidae were the most abundant, followed by Hydropsychidae and Calamoceratidae. The genus Glossosoma, Hydromanicus and Hydropsyche were the most abundant genus in this study. Results of the CCA ordination showed that total dissolved solids, electrical conductivity, and water temperature were the most important factors affecting the abundance and diversity of caddisfly larvae. Changes in the caddisfly larvae may indicate changes in physicochemical factors owing to urbanization or other anthropogenic. The results showed that the order Trichoptera, identified to the species or genus level, can potentially be used to assess environmental water quality status in freshwater ecosystems. This study suggested that species richness of aquatic insects may indicate the conservation value of the habitats because of their significant responses to environmental factors.
\end{abstract}

Keywords: Bioindicator; Caddisfly larvae; freshwater ecosystems; water quality variables

\section{ABSTRAK}

Pengaruh pemboleh ubah persekitaran dan potensi sebagai biopenunjuk tahap larva spesies Trichoptera dinilai dalam aliran kecil di utara Thailand dari Januari hingga November 2017. Sebanyak 1,191 larva lalat kadis individu yang tergolong dalam 7 famili dan 13 genus ditemui. Larva famili Glossosomatidae adalah yang paling banyak, diikuti oleh Hydropsychidae dan Calamoceratidae. Genus Glossosoma, Hydromanicus dan Hydropsyche adalah genus yang paling banyak dalam kajian ini. Hasil pentahbisan CCA menunjukkan bahawa jumlah pepejal terlarut, kekonduksian elektrik dan suhu air adalah faktor terpenting yang mempengaruhi kelimpahan dan kepelbagaian larva lalat kadis. Perubahan larva lalat kadis mungkin menunjukkan perubahan dalam faktor fizikokimia kerana perbandaran atau antropogen lain. Hasilnya menunjukkan bahawa urutan Trichoptera yang dikenali untuk spesies atau tingkat genus, berpotensi digunakan untuk menilai status kualiti air lingkungan di ekosistem air tawar. Kajian ini menunjukkan bahawa kekayaan spesies serangga akuatik dapat menunjukkan nilai pemuliharaan habitat kerana tindak balasnya yang signifikan terhadap faktor persekitaran.

Kata kunci: Biopenunjuk; ekosistem air tawar; larva lalat kadis; pemboleh ubah kualiti air

\section{INTRODUCTION}

Aquatic insects are macroinvertebrates that inhabit river and stream beds, lakes, and reservoirs and are associated with various types of substrates such as mineral sediments, detritus, macrophytes and filamentous algae (Rosenberg $\&$ Resh 1993). They are essential elements in lentic and lotic trophic webs, participating in the energy flow and nutrient cycling (Whiles \& Wallace 1997). They also are important food resources for fish (Wallace \& Webster
1996) and some insectivorous birds (Ward et al. 1995). The distribution of aquatic insects is the result of interactions among their ecological role, the physical conditions that characterize the habitat, and food availability (Merritt \& Cummins 1996). Thus, the community structure of aquatic insects depends on a number of factors, such as water quality, type of substrate, particle size of sediment, water flow, sediment organic matter availability, oxygen concentration as well as environmental conditions 
surrounding the watercourse (Buss et al. 2004; Ward et al. 1995). Because they reflect environmental changes, aquatic insects are often used as indicators of the effects of human activity on water systems and provide information on habitat and water quality (Woodcock \& Huryn 2007). The organic enrichment of water caused by both domestic and industrial effluents is a common anthropogenic impact on urban watercourses. This kind of pollution changes physical and chemical characteristics of lotic systems, thus affecting the assemblage of aquatic insects (Ward et al. 1995; Yap \& Rahim Ismail 2011).

The family-level of identification used to determine pollution tolerances could lead to erroneous interpretations or, at least, to a lack of sensitivity (Dohet 2002). The use of species level identification to monitor water quality pollution is much more precise than that of family or generic level (Resh \& Unzicker 1975). However, investigation focusing on species-level identifications for all macroinvertebrates represent a very time-consuming and expensive task, and cannot be conducted practically as a routine procedure for the assessment of water quality. Hence, an approach that focuses attention on a selected order or family of aquatic insects could have merit.

Amongst the aquatic insects, the order Trichoptera (or caddisflies) is probably the most widely distributed and the larvae are common in running water; they represent one of the relatively well-studied orders of aquatic insects in South East Asia (Malicky 2010). The larvae of many species coexist in running waters and are known to have specific habitat and environmental requirements (de Moor 2007). Caddisflies have been described as the most ecologically diverse group of aquatic insects, with 16,000 extant species worldwide (Morse 2018). As a numerically dominant group in rivers and streams, caddisflies are important to the functioning of freshwater ecosystems because of their ability to partition habitats and trophic resources (Wiggins 1996). Their response to perturbation and reliance on plant matter for food are reasons why caddisflies are widely used in several aspects of water quality monitoring (Resh 1992). Furthermore, their well-described biology and taxonomy facilitate the interpretation of water quality assessments.

Various studies (Dohet 2002; Lenat \& Resh 2001; Morse 2019; Pereira et al. 2012; Resh 1992) have pointed out that the need for keys to aid in the identification of the immature stages of caddisflies has become increasingly important with regard to understanding their potential as water quality indicators. Studies of Thai caddisflies have been confined mainly to descriptions of the adult stages, and relatively few larvae have been adequately characterized. Unfortunately, identification of larvae is required more frequently than the identification of adults, especially in biological surveys and biomonitoring. There is still a tremendous gap between the capacity to identify adult stages and the ability to recognize larvae or associate them with known adults. This is due, in part, because of the holometabolous life cycle of caddisflies and a pupal stage that complicates larval rearing and ensures that none of the features of the adult are reflected in the final-larval instar. As a result, reliable identification of the species basis on larvae alone is not possible, and adult material is indispensable for the determination of species. This obstacle also affects workers dealing with the relatively well-studied fauna of Europe and North America, although the situation is much worse in tropical Asia (Malicky 1983). In a study by Dohet (2002), macroinvertebrates were investigated from 292 sampling sites distributed throughout the country of Luxemburg. The study addressed the question: "are caddisflies an ideal group for the biological assessment of water quality in stream?". He suggested that the order Trichoptera (or caddisflies) was a good indicator for assessing water quality. However, his work focused mainly on the spatial variation of water quality perturbation, while temporal variation was not addressed. As we know, spatial and temporal variation affects the diversity and community of fauna, including Trichoptera (Clavier et al. 2015; Hong et al. 2010; Szivak et al. 2011). However, the studies, especially focusing on Trichoptera, were not well reported for Thailand. To help fulfill this gap in knowledge, the purpose of the present research was to examine temporal dynamics of caddisfly larvae community for assessing water quality deterioration in a northern Thailand's stream. The study also evaluated their relative adequacy to provide information about the conservational value of a freshwater habitat.

\section{MATERIALS AND METHODS}

\section{STUDY AREA AND SAMPLING STATION}

This study was conducted at the Nam Yian Stream (Figure 1), outside of the Doi Luang National Park, Phayao Province, northern Thailand. This site is a perennial stream which is located at $19^{\circ} 18.765^{\prime} \mathrm{N}, 099^{\circ} 42.686^{\prime} \mathrm{E}$ at an elevation of $579 \mathrm{~m}$ above sea-level. The substrate in the stream consisted of large exposed rocks with little movable intervening substrate. Riparian vegetation covered both sides of the stream. 

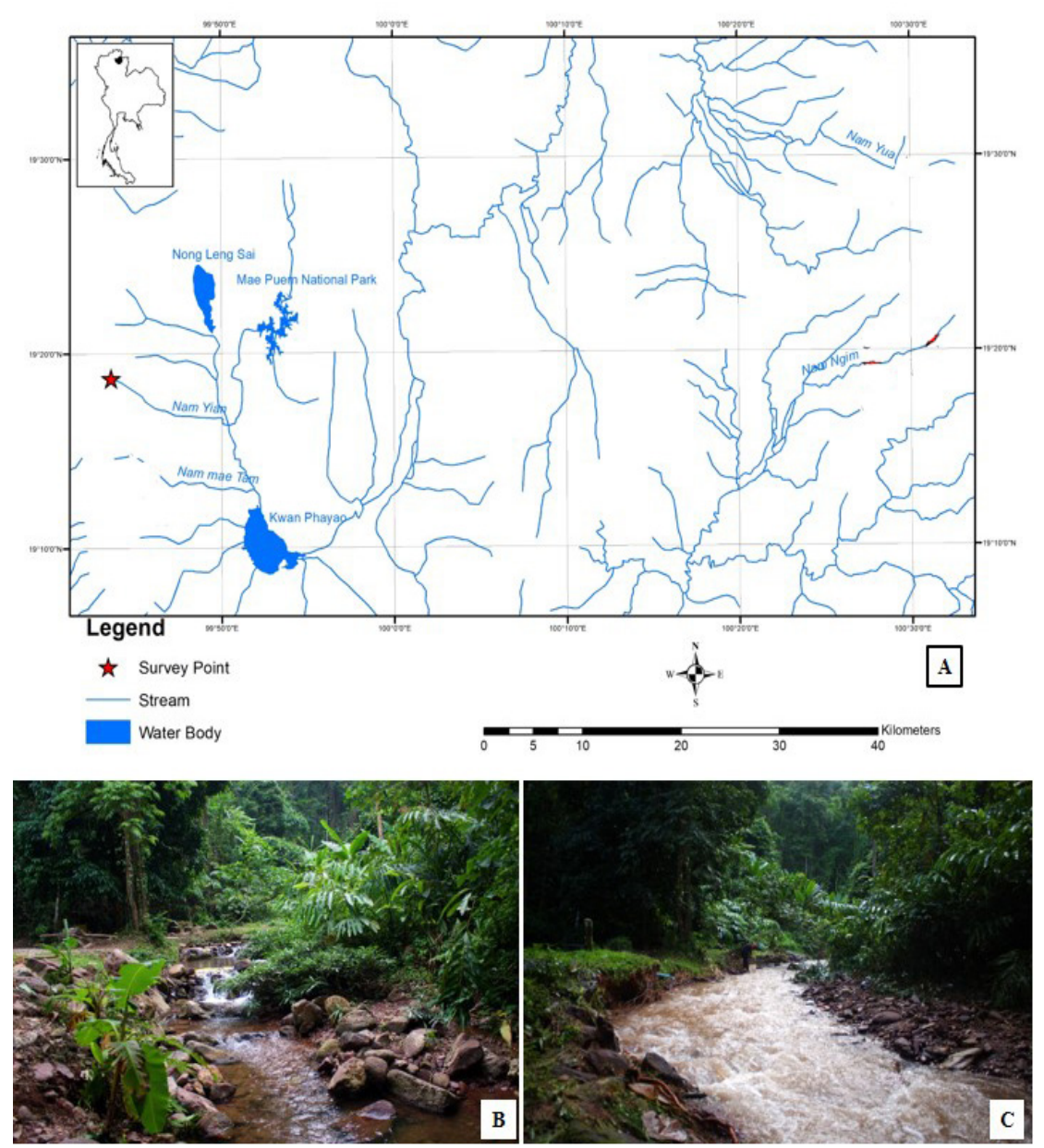

FIGURE 1. Map (A) showing the sampling site of the Nam Yian stream (B) and during a storm with flooding $(\mathrm{C})$ in Phayao Province, Northern Thailand

\section{TRICHOPTERA ADULT AND LARVAE COLLECTION AND IDENTIFICATION}

Caddisfly larvae and pupae were sampled using a D-frame aquatic hand net (Merritt \& Cummins 1996) with a dimension of $30 \times 30 \mathrm{~cm}$ frame, $250 \mu \mathrm{m}$ mesh, and 50 cm length. Sampling was conducted every month from January to November 2017, except for May, August, and December. A total of nine samples were collected. During each sampling period, a stretch of approximately $50 \mathrm{~m}$ of stream was chosen for collection of samples from the three target habitats - riparian vegetation, leaf litter, low gradient riffles, and pools. The duration of sampling in each habitat was $3 \mathrm{~min}$. Three replicate samples were collected during each sampling period, and all the insect samples from each sampling period were later pooled, replicate by replicate. The contents of the aquatic hand net were poured into white trays. Living caddisflies were sorted and transferred into properly-labelled plastic containers, preserved in $80 \%$ ethanol and taken back to the laboratory for analysis.

At the same sites where larvae and pupae were collected, adults were collected at the stream margin using black light traps (10-W fluorescent tube, 12-Volt DC battery) suspended across a white pan containing a detergent solution. Light trap sampling was conducted for $3 \mathrm{~h}$ per sampling period and occurred approximately $1 \mathrm{~h}$ before sunset and $1.5 \mathrm{~h}$ after sunset. Adult samples were collected on nights with a very clear sky when there was no full moon to help avoid light pollution competing with the trap. Insects attracted to the black light were collected the next morning, transferred into $80 \%$ ethyl alcohol, and transported to the laboratory. 
In the laboratory, caddisfly larvae and pupae were sorted in a petri dish and were identified to the genus and species level using taxonomic keys generated by several researchers (Dudgeon 1999; Prommi 2007; Wiggins 1996; Yule \& Sen 2004). All sorted samples were kept in properly-labelled vials containing $80 \%$ ethanol. Adult specimens were sorted and examined under a dissecting stereomicroscope. For most caddisfly species, the adult males were primarily used for making species determinations. The last two abdominal segments of adult male genitalia were removed and cleared by heating in $10 \% \mathrm{NaOH}$ at $70{ }^{\circ} \mathrm{C}$ for $30 \mathrm{~min}$. Specimen identifications were accomplished at the species level using Malicky (2010). For each species, specimen counts from collections at each sampling date were summed. The immature forms were associated with adults using the metamorphotype method, which relies on the collection of a pharate male in its pupal exuviae and with shed larval sclerites within the pupal case or shelter (Milne 1938; Wiggins 1996). Only species of caddisflies larvae were analyzed by using the canonical correspondence analysis (CCA) of PC-ORD Version 5.1 (McCune \& Mefford 1999).

\section{PHYSICOCHEMICAL WATER QUALITY PARAMETERS}

Environmental factors that influenced the abundance and assemblages of the caddisflies fauna at the study site also was investigated. Simultaneously, the selected physicochemical water quality parameters were measured at the sampling site prior to aquatic insect sampling. Three replicates of the physicochemical water quality parameters were recorded directly at each sampling site and included: $\mathrm{pH}$, measured by a $\mathrm{pH}$-meter Waterproof Model Testr30; water temperature (WT) measured by a hand-held thermometer; dissolved oxygen (DO), which was measured by a $\mathrm{HACH}^{\circledR}$ Model sensION 6 DO meter cyberScan Model DO110; and total dissolved solids (TDS) and electrical conductivity (EC) were measured by a EURECH CyberScan CON110 conductivity/TDS meter. The samples were measured once a month from January to November 2017, except for May, August and December.
DATA ANALYSIS

A one-way ANOVA $(P<0.05)$ was used to test for statistical differences between the means of the physicochemical water quality parameters in each month. Duncan's Multiple Range Test (DMRT) also was used for multiple comparisons of the means of the physicochemical variables (1).

$$
\text { Relative abundance }(\%)=(n i / N) \times 100
$$

where $n i$ is the number of individuals of each caddisfly larvae species, and $N$ is the total number of individuals of all caddisfly larvae species.

To determine if the species of caddisflies larvae in each month was related to environmental gradients, the canonical correspondence analysis (CCA), a direct multivariate gradient technique, was used. This multivariate method ordinates months, species, and environmental gradients simultaneously to show which environmental gradients are the most and least influential in determining species composition at a particular month. This analysis also was performed using PC-ORD version 5.1 (McCune $\&$ Mefford 1999). In the CCA, taxa constituting more than $0.1 \%$ of the total abundance were selected, and in total, 16 caddisflies larvae taxa were used in the analyses.

\section{RESULTS AND DISCUSSION}

\section{PHYSICOCHEMICAL PARAMETERS ON STREAM WATER QUALITY}

The means and standard deviations of the measured physicochemical water quality parameters at the sampling site taken during the nine sampling months are summarized in Table 1 . Water temperature did not significantly vary during the measurement period $(P>0.05)$, whereas dissolved oxygen, $\mathrm{pH}$, total dissolved solids and electrical conductivity varied significantly during the measurement period $(P<0.05)$.

TABLE 1 . Mean \pm SD water quality parameters of the Nam Yian stream, Northern Thailand from January to November 2017

\begin{tabular}{lccccc}
\hline Month/factors & $\mathrm{pH}$ & $\mathrm{DO}\left(\mathrm{mgL}^{-1}\right)$ & $\mathrm{EC}\left(\mu \mathrm{Scm}^{-1}\right)$ & $\mathrm{TDS}\left(\mathrm{mgL}^{-1}\right)$ & $\mathrm{WT}\left({ }^{\circ} \mathrm{C}\right)$ \\
\hline January & $9.05 \pm 0.01^{\mathrm{a}}$ & $9.58 \pm 0.24^{\mathrm{c}}$ & $265.33 \pm 16.80^{\mathrm{ab}}$ & $182.00 \pm 2.64^{\mathrm{b}}$ & $23.12 \pm 1.76^{\mathrm{a}}$ \\
February & $9.08 \pm 0.06^{\mathrm{a}}$ & $9.51 \pm 0.14^{\mathrm{c}}$ & $174.67 \pm 127.02^{\mathrm{a}}$ & $181.00 \pm 4.36^{\mathrm{b}}$ & $22.05 \pm 1.97^{\mathrm{a}}$ \\
March & $9.11 \pm 0.06^{\mathrm{a}}$ & $9.58 \pm 0.24^{\mathrm{c}}$ & $263.67 \pm 16.50^{\mathrm{ab}}$ & $181.00 \pm 2.64^{\mathrm{b}}$ & $22.67 \pm 1.61^{\mathrm{a}}$ \\
April & $9.06 \pm 0.01^{\mathrm{a}}$ & $9.73 \pm 0.13^{\mathrm{c}}$ & $257.67 \pm 25.93^{\mathrm{ab}}$ & $182.00 \pm 2.64^{\mathrm{b}}$ & $24.08 \pm 0.20^{\mathrm{a}}$ \\
June & $8.32 \pm 0.14^{\mathrm{b}}$ & $5.44 \pm 0.66^{\mathrm{a}}$ & $445.33 \pm 18.34^{\mathrm{d}}$ & $221.33 \pm 10.12^{\mathrm{c}}$ & $22.30 \pm 1.60^{\mathrm{a}}$ \\
July & $8.16 \pm 0.11^{\mathrm{b}}$ & $5.53 \pm 0.12^{\mathrm{a}}$ & $341.00 \pm 6.00^{\mathrm{bcd}}$ & $168.00 \pm 2.00^{\mathrm{b}}$ & $23.92 \pm 0.40^{\mathrm{a}}$ \\
September & $8.15 \pm 0.02^{\mathrm{b}}$ & $5.74 \pm 0.16^{\mathrm{ab}}$ & $266.00 \pm 27.87^{\mathrm{ab}}$ & $126.33 \pm 2.52^{\mathrm{a}}$ & $23.53 \pm 0.06^{\mathrm{a}}$ \\
October & $8.15 \pm 0.02^{\mathrm{b}}$ & $5.74 \pm 0.16^{\mathrm{ab}}$ & $299.33 \pm 47.01^{\mathrm{abc}}$ & $139.67 \pm 22.94^{\mathrm{a}}$ & $23.53 \pm 0.06^{\mathrm{a}}$ \\
November & $8.34 \pm 0.04^{\mathrm{b}}$ & $6.43 \pm 0.28^{\mathrm{b}}$ & $428.00 \pm 2.64^{\mathrm{cd}}$ & $213.67 \pm 1.15^{\mathrm{c}}$ & $23.99 \pm 0.12^{\mathrm{a}}$ \\
\hline
\end{tabular}

Values followed by the same letter are not significantly different $(\mathrm{p}>0.05)$ 
Water temperature values recorded during the sampling period ranged from 22.05 to $24.08^{\circ} \mathrm{C}$. This value falls within the optimal range for tropical freshwater. This was also corroborated by Prommi and Payakka (2015), who reported tropical freshwater temperature values ranging from 21 to $32{ }^{\circ} \mathrm{C}$. The variation in temperature observed was likely a result of low solar heat radiation across the stations. Inundation by run-off water into the stream also caused a reduction in temperature. The lowest mean value of dissolved oxygen $\left(5.44 \mathrm{mgL}^{-1}\right)$ was found in June, and the highest values were observed in April (9.73 $\left.\mathrm{mgL}^{-1}\right)$. The $\mathrm{pH}$ of the stream water was slightly alkaline (8.15-9.11). In natural waters, the $\mathrm{pH}$ scale runs from 0 to 14. A pH value of 7 is neutral; a $\mathrm{pH}$ less than 7 is acidic and greater than 7 represents base saturation or alkalinity. The highest mean value of total dissolved solids (221.33 $\left.\mathrm{mgL}^{-1}\right)$ and electrical conductivity $\left(445.33 \mu \mathrm{Scm}^{-1}\right)$ were observed in June and the lowest was observed in September (126.33 $\left.\mathrm{mgL}^{-1}\right)$.

The physicochemical characteristics in the Nam Yian stream varied during sampling period. In this study, physicochemical parameters ( $\mathrm{pH}, \mathrm{DO}, \mathrm{TDS}$ and $\mathrm{EC})$ were significantly different among the months. These results correspond with in water quality was related to the presence of aquatic insect order Trichoptera (Azrina et al. 2006; Fierro et al. 2015; Shokri et al. 2014; Yap \& Rahim Ismail 2011). Water temperature has been shown to greatly influences organisms in a stream and is inversely proportional to DO and electrical conductivity (Gimenez et al. 2015; Patrick et al. 2015). This is shown in this study whereby TDS and electrical conductivity increased in the rainy season, accompanied by a decrease in DO (Shafie et al. 2017). Low pH, high EC, and low dissolved oxygen (DO) were recorded, which characterize the slight degradation of water quality (Aazami et al. 2015). The $\mathrm{pH}$ value ranged from 8.15 at the lowest in the rainy season to 9.11 at the highest in the hot-dry season of the stream, indicating an increasing trend towards the hot-dry season.

Increased electrical conductivity is associated with organic pollution (which might have caused high levels of nitrogen) and high $\mathrm{pH}$ values (Gimenez et al. 2015). The $\mathrm{pH}$ in an aquatic ecosystem is important because it is related to biological productivity. The $\mathrm{pH}$ value ranges in this study from 8.15 to 9.11 , which is usually quite a good indicator of water quality (Dutta et al. 2014). Stream flow velocities and discharges are strongly influenced by natural effects and land use activities whereby the downstream in flat areas is characterized by agricultural activities and settlements resulting in high surface flow (Mori et al. 2015). The human intervention on the stream watershed in the form of agricultural land use and rural settlements have an effect on soil compaction, so it will cause changes in aquatic ecosystems, namely increasing river flow due to riverbank erosion, and changing physicochemical conditions in water (Doll et al. 2016; Reis et al. 2017).

\section{DIVERSITY OF ADULT CADDISFLIES}

The adult caddisflies were trapped by black light for comparison with the larvae samples. A total of 442 adult male caddisfly specimens, representing 10 families, 21 genus, and 33 species, were collected by light traps from January to November 2017. Adult caddisfly species displayed the highest abundance during February, April, October, and December and were least abundant in July, which is the rainy season. In tropical regions, rainfall is the primary factor influencing the temporal distribution of the macroinvertebrate fauna, including Trichoptera.

From these results, the species Cheumatopsyche carna, C. chryseis, C. chrysothemis, C. copia, C. lucida, Diplectrona aurovittata, Hydropsyche pallipenne, Hydromanicus serubabel, Potamyia flavata and Macrostemum midas were the most common and widely distributed Hydropsychidae species in the stream. The results of the adult caddisflies diversity assessment showed concordance with the results for the larvae. For example, the adults were found in the highest numbers in February while the larvae were found the lowest numbers were the lowest caused by the emerging adults. The species richness of adults was higher than the larvae because of the effectiveness of black light traps (Prommi \& Thani 2014).

\section{DIVERSITY OF CADDISFLY LARVAE}

Based on the results of the adult caddisflies species in this study, 5 species of unknown hydropsychid larvae could be associated with identifiable adults of Hydropsychidae. The 5 species of hydropsychid larvae comprised 4 genus: Diplectrona (D. aurovittata); Cheumatopsyche (C. tramota); Hydropsyche (H. pallipenne); Hydromanicus (H. klanklini and H. serubabel) (Table 2).

Thirteen genus in 7 families, with a total of 1,191 larvae, were collected (Table 2). The highest abundance of species was recorded in January and the lowest in February. The larvae of the family Glossosomatidae were the most abundant, followed by Hydropsychidae and Calamoceratidae. The genus Glossosoma, Hydromanicus, and Hydropsyche were the most abundance genus in this study. Principe (2008), in his study in different habitats of tropical streams in Costa Rica, found that aquatic macroinvertebrates assemblages were determined by stream habitat type. The relative abundance of caddisfly larvae recorded in each of sampling periods are presented in Table 2. 
TABLE 2. List of caddisfly larvae species in the Nam Yian stream, northern Thailand from January to November 2017

\begin{tabular}{|c|c|c|c|c|c|c|c|c|c|c|c|c|}
\hline Taxon/month & Jan & $\mathrm{Feb}$ & Mar & Apr & Jun & Jul & Sep & Oct & Nov & Total & $\% \mathrm{RA}^{*}$ & $\begin{array}{l}\text { Dominance } \\
\text { status }\end{array}$ \\
\hline \multicolumn{13}{|l|}{ Calamoceratidae } \\
\hline Ganonema sp. & 8 & 1 & 3 & 10 & 43 & 1 & & & & 66 & 5.54 & Subdominant \\
\hline Anisocentropus sp. & 4 & 8 & & & 1 & 1 & 1 & & & 15 & 1.26 & Recedent \\
\hline \multicolumn{13}{|l|}{ Glossosomatidae } \\
\hline Agapetus sp. & 21 & & & & & & & & & 21 & 1.76 & Recedent \\
\hline Glossosoma sp. & 72 & 127 & 4 & 1 & & 18 & 56 & 1 & 24 & 303 & 25.44 & Dominant \\
\hline \multicolumn{13}{|l|}{ Rhyacophilidae } \\
\hline Rhyacophila sp. & 2 & & & & & & & & & 2 & 0.17 & Subrecedent \\
\hline \multicolumn{13}{|l|}{ Philopotamidae } \\
\hline Chimarra sp. & 2 & 1 & 13 & 5 & & & & 3 & 2 & 26 & 2.18 & Recedent \\
\hline \multicolumn{13}{|l|}{ Lepidostomatidae } \\
\hline Lepidostoma sp. & 12 & 1 & 2 & 2 & & & 2 & & & 19 & 1.60 & Recedent \\
\hline \multicolumn{13}{|l|}{ Hydropsychidae } \\
\hline Hydromanicus klanklini & 23 & 8 & & 13 & 10 & 3 & 22 & 8 & 33 & 120 & 10.08 & Dominant \\
\hline Hydromanicus serubabel & 48 & & 11 & 13 & 9 & 6 & 17 & 6 & 25 & 135 & 11.34 & Dominant \\
\hline Hydropsyche pallipenne & 11 & & 15 & 17 & 18 & 2 & 11 & & 63 & 137 & 11.50 & Dominant \\
\hline $\begin{array}{l}\text { Diplectrona } \mathrm{cf} . \\
\text { Aurovittata }\end{array}$ & 29 & & 7 & 5 & & 1 & & 3 & 48 & 93 & 7.81 & Subdominant \\
\hline Cheumatopsyche tramota & 22 & & & & 5 & & & & & 27 & 2.27 & Recedent \\
\hline Cheumatopsyche spp. & 23 & & 29 & 15 & & 1 & & 2 & 45 & 115 & 9.66 & Subdominant \\
\hline Hydropsyche sp. & 24 & & 7 & 3 & 18 & 9 & & 4 & 39 & 104 & 8.73 & Subdominant \\
\hline Macrostemum sp. & & & 1 & & 1 & & 1 & & 3 & 6 & 0.50 & Subrecedent \\
\hline \multicolumn{13}{|l|}{ Leptoceridae } \\
\hline Setodes sp. & & & & & & & & & 2 & 2 & 0.17 & Subrecedent \\
\hline Total genus & 14 & 6 & 10 & 10 & 8 & 9 & 7 & 7 & 10 & & & \\
\hline Total individual & 301 & 146 & 92 & 84 & 105 & 42 & 110 & 27 & 284 & 1,191 & 100.00 & \\
\hline
\end{tabular}

* RA $<1$ = Subrecedent; 1.1-3.1 = Recedent; 3.2-10 = Subdominant; 10.1-31.6 = Dominant; $>31.7 \%=$ Eudominant (Engelmann 1978)

\section{CADDISFLY LARVAE AND ITS RELATIONSHIP WITH STREAM WATER QUALITY}

The total variance of the caddisflies immature species assemblages determined by the $\mathrm{C}$ was 1.0507 . The total variance or inertia indicates the total amount of variability that might potentially be explained. The first three correlations between the biotic data set and the abiotic data set were $0.968,0.946$, and 0.959 , respectively. The first three axes derived from the CCA accounted for $71.8 \%$ of the variation of the caddisflies immature species assemblages (Table 3 ).

The CCA demonstrated that variables such as electric conductivity and total dissolved solids were positively correlated with the first axis, whereas water temperature was positively correlated with the second axis (Table 3 ). In the CCA, the three first axis explained 0.433, 0.220, and 0.107 of variation, respectively, and were strongly influenced by electrical conductivity, total dissolved solids and water temperature (Figure 2).

The eigenvalues associated with each axis actually represent the correlation coefficient between months and environmental variables. An eigenvalue close to 1 represents a high degree of correspondence between months and environmental variables. High eigenvalues (greater than 1) are always associated with long and strong environmental gradient lines (Palmer 1993). In the present 
study, the correspondence was measured between months and variables, thus, the total eigenvalue of 0.76 indicated a medium to high degree of correspondence between species and month.

TABLE 3. Canonical Correspondence Analysis (CCA) summary statistics for the caddisfly larvae and water quality variables, including eigenvalues, variance explained, and Pearson and Kendall Correlation values for the first three canonical axes

Number of canonical axes: 3

Total variance ("inertia") in the species data: 1.0575

\begin{tabular}{lccc}
\hline & Axis I & Axis II & Axis III \\
Eigenvalue & 0.433 & 0.220 & 0.107 \\
Variance in species data & & & 10.1 \\
$\quad$ \% of variance explained & 41.0 & 20.8 & 71.8 \\
$\quad$ Cumulative \% explained & 41.0 & 61.8 & 0.959 \\
Pearson Correlation, Spp-Envt* & 0.968 & 0.946 & 0.833 \\
Kendall (Rank) Corr., Spp-Envt & 0.778 & 0.667 & 0.745 \\
pH & -0.247 & 0.148 & 0.713 \\
Dissolved oxygen (DO) & -0.285 & 0.271 & -0.570 \\
Electrical conductivity (EC) & 0.728 & -0.079 & -0.260 \\
Total dissolved solids (TDS) & 0.548 & -0.146 & -0.487 \\
Water temperature (WT) & 0.399 & 0.598 & \\
\hline
\end{tabular}

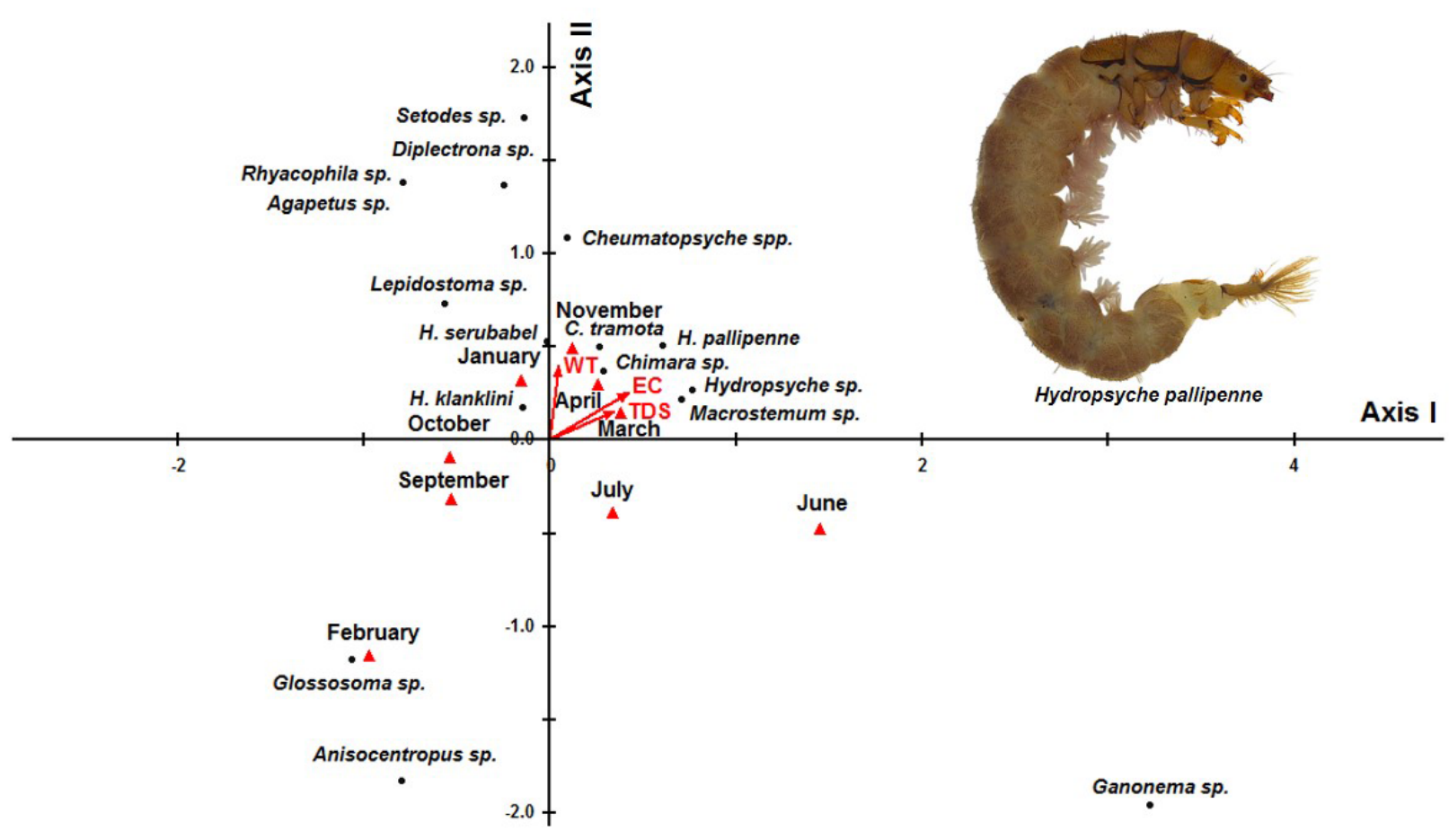

FIGURE 2. Canonical Correspondence Analysis (CCA) showing the correlation between caddisflies larvae, sampling time, and physicochemical variables ( $\bullet$, species; $\boldsymbol{\Lambda}$, month; lines, environmental variables; WT, water temperature; EC, electrical conductivity; TDS, total dissolved solids) 
The CCA associations of the Trichoptera species data with the environmental variables are graphically displayed in Figure 2. The CCA ordination diagram clearly separated the months on the basis of aquatic insect order Trichoptera community structure. The direction and length of each arrow indicates the direction and rate of maximum change in each variable. During March, April, and November, most of the species showed dependence on water temperature, electrical conductivity, and total dissolved solids. Taxa with positive scores on the first CCA axis included Hydromanicus klanklini, H. serubabel, Hydropsyche pallipenne, Cheumatopsyche tramota, Diplectrona sp., Hydropsyche sp., and Macrostemum sp.

Electrical conductivity is a function of total dissolved solids known as ion concentration, which determines the quality of water (Tariq et al. 2006). Electrical conductivity itself is not a human or aquatic health concern, but because it is easily measured, it can serve as an indicator of other water quality problems. If the conductivity of a stream suddenly increases, it indicates that there is a source of dissolved ions in the vicinity. Therefore, conductivity measurements can be used as an efficient way to locate potential water quality problems (Siddaramu \& Puttaiah 2013). All natural waters contain some dissolved solids due to the dissolution and weathering of rock and soil. Some, but not all, dissolved solids act as conductors and can contribute to conductance. Waters with high total dissolved solids are unpalatable and potentially unhealthy. Electrical conductivity and total dissolved solids did correlate with Hydromanicus klanklini, H. serubabel, Hydropsyche pallipenne, Cheumatopsyche tramota, Diplectrona sp., Hydropsyche sp., and Macrostemum sp. in this study.

Water temperature was positively correlated with axis II, this axis was interpreted as a gradient of increasing values of water temperature. Taxa with negative scores on axis II included Glossosoma sp. and Anisocentropus sp. (Figure 2). Decreasing temperature also increases the water capability to saturate dissolved oxygen, which highly influences the occurrence and distribution of pollution-sensitive taxa (Hauer \& Hill 2007). The higher water temperatures probably favored the densities and diversity of Hydropsychidae in the Mae Tao and Mae Ku watersheds northern Thailand (Prommi \& Payakka 2015). Temperature is one of the major factors determining the distribution of Hydropsychidae, where most of the species exhibit higher densities in warmer waters (Kimura et al. 2008). Water temperature significantly affects abundance, diversity, and distribution of aquatic insects (Burgmer et al. 2007; Lessard \& Hayes 2003; Li et al. 2012), as it influences their embryonic development, growth, emergence, metabolism and survivability (Hauer \& Hill 2007).
The result of the CCA showed the strong relationship between caddisfly species abundance and season. Glossosoma sp. were found in the highest numbers in February which were grouped together on axis II. Another group was the months of March, April, June, and July 2017. Hot dry season normally runs from March to early May, while from late May to October is rainy season. September and October are in rainy season which were grouped together as well as a group of cool dry season of November and January. In each group of the months showed strong correlation with caddisfly species. Dudgeon (2001) explained that the ecology of Asian rivers is profoundly influenced by monsoons, which creates a characteristic pattern of seasonality; predictable periods of drought and water scarcity during the dry season alternate with intervals of increased discharge, when flood plains are inundated during the wet season. This has important implications for aquatic productivity. Seasonal precipitation has been suggested as another important factor influencing the composition and temporal abundance of aquatic insects in tropical streams (Masteller \& Buzby 1993). Therefore, we suggest that seasonal variation- at least dry and wet seasons- must be a consideration in using the Trichoptera for water quality assessment. The very low number of Trichoptera species tolerant to environmental stresses limits this order's use as an ideal bio-indicator (Dohet 2002). However, the publications indicated that Hydropsychidae is usually considered as very tolerant to organic pollution in rapid bioassessment protocols used in Europe and Thailand and based on a family level of identification (Armitage et al. 1983; Mustow 2002). Species of Hydropsyche are considered as the last Trichoptera that disappear in polluted water and the first that reappear as water quality improves downstream of a polluted area (Dohet 2002). In this research, the Hydropsychids were found as the highest species richness, such as Hydropsyche pallipenne (Figure 2), Hydromanicus serubabel, and Hydromanicus klanklini. A report of Prommi et al. (2016) indicated that hydropsychids were also used to evaluate the water quality of a stream in Tak Province (in Northern Thailand) surrounded by the different land use types. The results indicated that Chuematopsyche carmentis and $C$. lucida were positively correlated with organic pollution especially $\mathrm{NH}_{3}-\mathrm{N}$, while Potamyia flavata was positively correlated with $\mathrm{NO}_{3}-\mathrm{N}$. Therefore, the relative sensitivity to organic pollution of several species belongs to the Hydropsychidae family.

Ratia et al. (2012) found that Hydropsychids were the useful indicator for the delayed recovery of a watercourse polluted by pulp and paper industry. It was found that Hydropsychid's gill abnormalities remained elevated for 
at least 20 years following the closure of the industry, thus indicating the long-term impact of the polluted water on their population health. Therefore, information on the autecology studies are needed and will provide useful details for water quality bioindicator assessment.

\section{CONCLUSION}

The aim of this study was to investigate the caddisfly communities in relation to water quality variables in order to explore the bioindication potential of caddisfly larvae for assessing water quality deterioration in northern Thailand. The research result strongly suggests to use the Trichoptera to evaluate the water quality with the concerning to seasonal variation, at least two sampling periods of wet and dry seasons. However, detailed sitespecific information is not usually available in developing countries. Consequently, baseline surveys of the kind conducted in this study are necessary to produce a general view of the biological communities present within a particular area. Understanding responses of aquatic insects to environmental changes could be of immense help to the planners or policy makers thereby allowing them to put into practice a more informed, scientifically-based management plan for water quality.

\section{ACKNOWLEDGEMENTS}

This research work was supported by the National Science and Technology Development Agency (NSTDA) grant number FDA-CO-2562-10029-TH.

\section{REFERENCES}

Aazami, J., Sari, A.E., Abdoli, A., Sohrabi, H. \& Van den Brink, P.J. 2015. Assessment of ecological quality of the Tajan River in Iran using a multimetric macroinvertebrates index and species traits. Environmental Management 56(1): 260-269.

Armitage, P.D., Moss, D., Wright, J.F. \& Furse, M.T. 1983. The performance of a new biological water quality score system based on macroinvertebrates over a wide range of unpolluted running-water sites. Water Research 17(3): 333-347.

Azrina, M.Z., Yap, C.K., Ismail, A.R., Ismail, A. \& Tan, S.G. 2006. Anthropogenic impacts on the distribution and biodiversity of benthic macroinvertebrates and water quality of the Langat River, Peninsular Malaysia. Ecotoxicology and Environmental Safety 64(3): 337-347.

Burgmer, T., Hillebrand, H. \& Pfenninger, M. 2007. Effects of climate-driven temperature changes on the diversity of freshwater macroinvertebrates. Oecologia 151(1): 93-103.

Buss, D.F., Baptista, D.F., Nessimain, J.L. \& Egler, M. 2004. Substrate specificity, environmental degradation and disturbance structuring macroinvertebrate assemblages in Neotropical streams. Hydrobiologia 518(1-3): 179-188.
Clavier, S., Cottet, M., Favriou, P., Phabmixay, S.S. \& Guedant, P. 2015. Spatial and temporal variation of benthic macroinvertebrates in the Nam Theun 2 Reservior (Lao PDR). Hydroécologie Appliquée 19: 217-243.

de Moor, F.C. 2007. Regional biogeographical differences in Trichoptera diversity in South Africa: Observed Patterns and Processes. In Proceedings of the XII International Symposium on Trichoptera. Caddis Press. pp. 211-218.

Dohet, A. 2002. Are caddisflies an ideal group for the biological assessment of water quality in stream? In Proceedings of the $X^{\text {th }}$ International Symposium on Trichoptera. Goecke \& Evers. pp. 507-520.

Doll, B., Jennings, G., Spooner, J., Penrose, D., Usset, J., Blackwell, J. \& Fernandez, M. 2016. Can rapid assessments predict the biotic condition of restored streams? Water 8(143): 1-22.

Dudgeon, D. 2001. The ecology of tropical Asian rivers and streams in relation to biodiversity conservation. Annual Review of Ecology and Systematics 31(1): 239-263.

Dudgeon, D. 1999. Tropical Asian Stream: Zoobenthos, Ecology and Conservation, Hong Kong: Hong Kong University Press. pp. 207-290.

Engelmann, H.D. 1978. Zur dominanzklassifizierung von bodenarthropoden. Pedobiologia 18(5-6): 378-380.

Fierro, P., Bertran, C., Mercado, M., Pena Cortes, F., Tapia, J., Hauenstein, E., Caputo, L. \& Vargas Chacoff, L. 2015. Landscape composition as a determinant of diversity and functional feeding groups of aquatic macroinvertebrates in southern rivers of the Araucanía, Chile. Latin American Journal of Aquatic Research 43(1): 186-200.

Gimenez, B.C.G., Lansac-Tôhaa, F.A. \& Higutia, J. 2015. Effect of land use on the composition, diversity and abundance of insects drifting in neotropical streams. Brazilian Journal of Biology 75(4): 52-59.

Hauer, F.R. \& Hill, W.R. 2007. Temperature, light and oxygen. In Methods in Stream Ecology. 2nd ed., edited by Hauer, F.R. \& Lamberti, G.A. San Diego: Academic Press/Elsevier. pp. 103-117.

Hoang, T.H., Lock, K., Chi Dang, K., De Pauw, N. \& Goethals, P.L.M. 2010. Spatial and temporal patterns of macroinvertebrate communities in the Du River basin in northern Vietnam. Journal of Freshwater Ecology 25(4): 637-647.

Kimura, G., Inoue, E. \& Hirabayashi, K. 2008. Seasonal abundance of adult caddisfly (Trichoptera) in the middle reaches of the Shinano River in Central Japan. In Proceedings of the Sixth International Conference on Urban Pests, edited by Robinson, W.H. \& Bajomi, D. Hungary: OOK-Press Kft. pp. 259-266.

Lenat, D.R. \& Resh, V.H. 2001. Taxonomy and stream ecology - the benefits of genus- and species-level identifications. Journal of the North American Benthological Society 20(2): 287-298.

Lessard, J.L. \& Hayes, D.B. 2003. Effect of elevated water temperature on fish and macroinvertebrate communities below small dams. River Research and Applications 19(7): 721-732. 
Li, F., Cai, Q., Jiang, W. \& Qu, X. 2012. Macroinvetebrate relationships with water temperature and water flow in subtropical monsoon streams of central China: Implications for climate change. Fundamental and Applied Limnology 180(3): 221-231.

Malicky, H. 2010. Atlas of Southeast Asian Trichoptera. Chiang Mai University. Ph.D. Thesis (Unpublished).

Malicky, H. 1983. Caddisflies (Trichoptera) from Parakrama Samudra, an ancient man-made lake in Sri Lanka. In Limnology of Parakrama Samudra-Sri Lanka, edited by Schiemer, F. The Hague: Dr. W. Junk Publishers. pp. 227-228.

Masteller, E.C. \& Buzby, K.M. 1993. Composition and temporal abundance of aquatic insect emergence from a tropical rainforest stream, Quebrada-Prieta, at El-Verde, Puerto-Rico: Introduction. Journal of the Kansas Entomological Society 66(2): 133-139.

McCune, B. \& Mefford, M.J. 1999. PC-ORD: Multivariate Analysis of Ecological Data; Version 4. Oregon: MjM Software Design.

Merritt, R.W. \& Cummins, K.W. 1996. An Introduction to the Aquatic Insects of North America. 3rd ed. Kendall/Hunt: Publishing Company.

Milne, M.J. 1938. The metamorphotype method in Trichoptera. Journal of the New York Entomological Society 46(4): 435437.

Mori, G.B., de Paula, F.R., de Barros Ferraz, S.F., Camargo, A.F.M. \& Martinelli, L.A. 2015. Influence of landscape properties on stream water quality in agricultural catchments in Southeastern Brazil. International Journal of Limnology 51(1): 11-21.

Morse, J.C. 2018. Trichoptera World Checklist. http://entweb. clemson.edu/database/. Accessed on 2 February 2020.

Morse, J.C., Frandsen, P.B., Graf, W. \& Thomas, J.A. 2019. Diversity and ecosystem services of Trichoptera. Insects 10(125): 1-25.

Mustow, S.E. 2002. Biological monitoring of rivers in Thailand: Use and adaptation of the BMWP score. Hydrobiologia 479: 191-229.

Palmer, M.W. 1993. Putting things in even better order: The advantages of canonical correspondence analysis. Ecology 74: 2215-2230

Patrick, M.S., Marie, T.M.J. \& Nadine, M.L. 2015. Benthic macroinvertebrates as indicators of water quality: A case-study of urban Fauna Stream (in Kinshasa, Democratic Republic of Congo). Open Journal of Water Pollution and Treatment 2(1): 8-24.

Pereira, L.R., Cabette, H.S.R. \& Juen, L. 2012. Trichoptera as bioindicators of habitat integrity in the Pinda1'ba river basin, Mato Grosso (Central Brazil). Annales de Limnologie - International Journal of Limnology 48: 295-302.

Principe, R.E. 2008. Taxonomic and size structures of aquatic macroinvertebrate assemblages in different habitats of tropical streams, Costa Rica. Zoological Studies 47: 525-534.

Prommi, T. 2007. Taxonomy of hydropsychidae (trichopteran) in mountain streams of Southern Thailand. Prince of Songkla University. Ph.D. Thesis (Unpublished).
Prommi, P. \& Payakka, A. 2015. Aquatic insect biodiversity and water quality parameters of streams in Northern Thailand. Sains Malaysiana 44(5): 707-717.

Prommi, P. \& Thani, I. 2014. Diversity of Trichoptera fauna and its correlation with water quality parameters at Pasak Cholasit reservoir, Central Thailand. Environment and Natural Resources Journal 12(2): 35-41.

Prommi, T., Peumwarunyoo, P. \& Mansukphol, P. 2016. Distribution of hydropsychidae (insecta, trichoptera) and water quality parameters in Mae Tao Creek, Mae Sot District, Tak Province, northern Thailand. Zoosymposia 10: 413-423.

Ratia, H., Vuori, K. \& Oikari, A. 2012. Caddis larvae (Trichoptera, Hydropsychidae) indicate delaying recovery of a watercourse polluted by pulp and paper industry. Ecological Indicators 15: $217-226$

Reis, D.F.D., Salazar, A.E., Machado, M.M.D., Couceiro, S.R.M. $\&$ Morais, P.B.D. 2017. Measurement of the ecological integrity of Cerrado streams using biological metrics and the index of habitat integrity. Insects 8(10): 1-15.

Resh, V.H. 1992. Recent trends in the use of Trichoptera in Water Quality Monitoring. Proceedings of the VII ${ }^{\text {th }}$ International Symposium on Trichoptera. Backhuys Publishers. pp. 289-291.

Resh, V.H. \& Unzicker, J.D. 1975. Water quality monitoring and aquatic organisms: The importance of species identification. Journal of the Water Pollution Control Federation 47: 9-19.

Rosenberg, D.M. \& Resh, V.H. 1993. Freshwater Biomonitoring and Benthic Macroinvertebrates. Academic Press: New York.

Shafie, M.S.I., Wong, A.B.H., Harun, S. \& Fikri, A.H. 2017. Land use influence on the aquatic insect communities on tropical forest streams of Liwagu River, Sabah, Malaysia. Aquaculture, Aquarium, Conservation \& Legislation International Journal of the Bioflux Society 10(2): 341-352.

Shokri, M., Rossaro, B. \& Rahmani, H. 2014. Response of macroinvertebrates communities to anthropogenic pressures in Tajan River (Iran). Biologia 69(10): 1395-1409.

Siddaramu, D. \& Puttaiah, E.T. 2013. Physicochemical characteristics of Balagala Kere and Purali Kere of Shimoga District, Karnataka, India. International Journal of Advanced Research 1(8): 313-321.

Szivak, I., Mora, A. \& Torok, J.K. 2011. Spatio-temporal variations of caddisfly in a chalk stream, Balaton Upland, Hungary. Zoosymposia 5: 439-452.

Tariq, M., Ali, M. \& Shah, Z. 2006. Characteristics of industrial effluents and their possible impacts on quality of underground water. Soil \& Environmental 25(1): 64-69.

Wallace, J.B. \& Webster, J.R. 1996. The role of macroinvertebrates in stream ecosystem function. Annual Review of Entomology 41: 115-139.

Ward, D., Holmes, N. \& Jose, P. 1995. The New Rivers and Wildlife Handbook. Bedfordshire: Royal Society for the Protection of Birds.

Whiles, M.R. \& Wallace, J.B. 1997. Leaf litter decomposition and macroinvertebrate communities in headwater streams draining pine and hardwood catchments. Hydrobiologia 353(1): 107-119. 
Wiggins, G.B. 1996. Larvae of the North American Caddisfly Genera (Trichoptera). 2nd ed. Toronto: University of Toronto Press.

Woodcock, T.S. \& Huryn, A. 2007. The response of macroinvertebrate production to a pollution gradient in a headwater stream. Freshwater Biology 52(1): 77-196.

Yap, C.K. \& Rahim Ismail, A. 2011. Relationships of distribution of macrobenthic invertebrates and the physico-chemical parameters from Semenyih River by using correlation and multiple linear regression analyses. Pertanika Journal of Tropical Agricultural Science 34(2): 229-245.

Yule, C.M. \& Sen, Y.H. 2004. Freshwater Invertebrates of the Malaysian Region. Selangor: Aura Productions Sdn. Bhd.

Thamsenanupap, P.

Faculty of Environment and Resource Studies

Mahasarakham University

Mahasarakham, 44150

Thailand
Seetapan, K.

School of Agriculture and Natural Resources

University of Phayao, Tumbol Maeka

Muang District

Phayao Province, 56000

Thailand

Prommi, T.*

Faculty of Liberal Arts and Science

Kasetsart University

Kamphaeng Saen Campus

Nakhon Pathom Province, 73140

Thailand

*Corresponding author; email: faastop@ku.ac.th

Received: 13 April 2020

Accepted: 9 August 2020 